\title{
Alkali Pretreated Rice Straw as an Inexpensive Substrate for Single-Cell Protein Production by Saccharomyces cerevisiae
}

\author{
Sh.M. Husseiny ${ }^{*}$, M.S. El-Gamal ${ }^{2}$, A.I.S. Ahmed ${ }^{3}$, A.M. \\ Abd El-rhman ${ }^{2}$ and H.M.H. Khashaba ${ }^{3}$ \\ ${ }^{1}$ Botany department, Faculty of Women for Art, Science \& \\ Education, Ain Shams University, ${ }^{2}$ Botany and Microbiology \\ Department, Faculty of Science, Al-Azhar University and \\ ${ }^{3}$ Special Food and Nutrition Department, Food Technology \\ Research Institute, Agriculture Research Center, Giza, Egypt.
}

\begin{abstract}
N INVESTIGATION concerning the bioconversion of an alkalitreated rice straw to single cell protein under fermentation conditions by Saccharomyces cerevisiae was done. The optimal environmental and nutritional conditions, which resulted in the highest protein production by $S$. cerevisiae can be summarized as following; incubation temperature, $30^{\circ} \mathrm{C}$; incubation periods, $48 \mathrm{~h}$; $\mathrm{pH}$ of 4.5 ; inoculum size $1 \mathrm{ml} / 100 \mathrm{ml}$ from a heavy spore suspension of $95 \times 10^{7}$ Colony Forming Unit (CFU) $/ \mathrm{ml}, 2 \mathrm{~g} \%$ rice straw concentrations; $\mathrm{NH}_{4} \mathrm{H}_{2} \mathrm{PO}_{4}$ as best nitrogen source; carbon source $2.5 \mathrm{~g} \%$ of lactose. The highest yields of single cell protein were obtained under static condition. High contents of nutritional compounds such as protein, mineral, carbohydrate, lipid, vitamins and amino acids were determined in the produced yeast biomass. These results show that Saccharomyces cerevisiae could be suitable for single cell protein production from cheap waste products.
\end{abstract}

Keywords: Single Cell Protein, Rice straw, Saccharomyces cerevisiae

Technically, single cell protein (SCP) is the manufacture of cell mass using microorganisms by culturing on abundantly available wastes. Algae, fungi and bacteria are the chief sources of the microbial protein that can be utilized as SCP (Anupama and Ravindra, 2000). It refers to the dried cells of microorganisms such as yeast, bacteria, fungi and algae which grow in large-scale culture systems for use as protein sources in human food or animal feed (Prado-Rubio et al., 2010 and Zepka et al., 2010). Not only proteins but also free amino acids, lipids, carbohydrates, vitamins and minerals are often included in the single cell protein term (Zheng et al., 2005; Rajoka et al., 2006; Gao et al., 2007; Zhang et al., 2008 and Rasoul-Amini et al., 2009). In particular protein supply possesses a problem since essential amino acids can not be replaced. One possible solution to this problem is SCP production. Much interest has been focused on the potential of converting agriculture, industrial, municipal or forestry wastes to microbial protein.

*Corresponding author: Husseinymoussa@ women.asu.edu.eg,Mobile :0020201222867353 
The production of the microbial biomass is achieved either by a submerged or solid state fermentation (SSF) process. After fermentation, biomass harvested and may be used as a protein source or subjected to processing steps like washing, cell disruption, protein extraction and purification. In general, the high production rates and protein yields as well as ease of production control make SCP more attractive as a protein source compared with conventional plant and animal sources (Xiao et al., 2009).

Microorganisms have high protein content and short growth times, leading to rapid biomass production, which can be continuous and independent from the environmental conditions. The use of fungi, especially yeasts, for SCP production is more convenient, as they can be easily propagated using cheap raw materials and easily harvested due to their bigger cell sizes and flocculation abilities. Moreover, they contain lower amounts of nucleic acids than bacteria (Ravindra, 2000). The main categories of their use at present were as source of single-cell protein for application in waste treatment, as feedstock for biofuel production and as a source of biochemical components of industrial interest Zepka et al. (2010).

Many raw materials have been studied as substrates for the production of SCP. In many cases, these raw materials have been hydrolyzed by physical, chemical and enzymatic methods before use (Becker, 2007 and Gao et al., 2007) . Increasing concern about pollution that occurs from agricultural and industrial wastes has stimulated interest in converting waste materials into commercially valuable products, especially SCP (Ugwuanyi, 2008; Prado-Rubio et al., 2010 and Silva et al., 2011).

Rice straw is a by-product of rice production, and a great bio-resource as raw biomass material for manufacturing value-adding protein for animal feedstock, which has been paid more and more attention (Zheng et al., 2005).

In our research, studies had been aimed primarily to the use of agro-industrial wastes for the production of (SCP) with resultant protection of environment. Rice straw was chosen as fermentation substrate for this study, firstly, it is considered as a typical representative of agro-industrial wastes, which is an essential and readily available commodity in the developing countries. Secondly, they are universal and commonly used agricultural crops with essential elements for pollutions and are readily available in Egypt. Thus, degradation of these wastes requires the selection of microorganisms which are able to assimilate them. The cultivation of microbial biomass as single cell protein (SCP) has been studied.

\section{Materails and Methods}

Yeast Species

Saccharomyces cerevisiae was obtained from Botany and Microbiology Department, Faculty of science, Al-Azhar University, Cairo, Egypt.

Agricultural Wastes

Rice straw was collected from Minet El-Gamh city in El-Sharkia Governorate, Egypt.

Egypt. J. Bot., 56, No. 1 (2016) 


\section{Alkali- Pretreatment}

Rice straw was firstly air dried put in oven at $60^{\circ} \mathrm{C}$ for $24 \mathrm{hr}$ and grind in electrical blender for approximately $5 \mathrm{~min}$. Dried grinded rice straw wastes were treated by sodium hydroxide according to the method of Zhu et al. (2005). They were autoclaved at $121^{\circ} \mathrm{C}$ for $30 \mathrm{~min}$. The pretreated rice straw was allowed to cool and subsequently filtered by cloth-sheet and washed with tap water to neutral $\mathrm{pH}$. It was then dried at $60^{\circ} \mathrm{C}$ in an oven for $12 \mathrm{hr}$, and then used at $1 \%(\mathrm{w} / \mathrm{v})$ in basal medium for single cell protein production.

\section{Cultivation Medium}

Yeast Malt Glucose Peptone Agar (YMGPA) was used to cultivate and preserve Saccharomyces cerevisiae

\section{Single Cell Protein Production Medium}

Czapek-Dox's was prepared using a basal medium, consisted of $(\mathrm{g} / \mathrm{l})$ : sodium nitrate, 3.0; potassium chloride, 0.5; magnesium sulfate, 0.5 and potassium dihydrogen phosphate, 1.0. The $\mathrm{pH}$ value adjusted to $4.5-5$ by citrate-phosphate buffer. The medium was dispensed in $100 \mathrm{ml}$ portion $250 \mathrm{ml}$ Erlenmeyer flasks and supplemented with $1 \mathrm{~g}$ of alkali-treated rice straw.

All flasks were sterilized at $121^{\circ} \mathrm{C}$ for 15 min. Each flask was inoculated with $1 \mathrm{ml}$ of $S$. cerevisiae suspension containing $\left(95 \times 10^{7}\right) \mathrm{CFU} / \mathrm{ml}$. They incubated at $30^{\circ} \mathrm{C}$ for $24 \mathrm{hr}$. At the end of the incubation period, yeast cells were collected by centrifugation at $4000 \mathrm{rpm}$ at $4^{\circ} \mathrm{C}$ for $10 \mathrm{~min}$. and washed twice with distilled water. The obtained SCP was then dried at $70^{\circ} \mathrm{C}$ until the dry weight was constant for analysis.

\section{Protein Determination}

Extraction of Protein from Yeast Cells with Sodium Hydroxide

The extraction was achieved according to the method of Herebert et al. (1971) in which Twenty milliliters of $1 \mathrm{~N} \mathrm{NaOH}$ was added to $5 \mathrm{~g}$ yeast biomass in $15 \mathrm{ml}$ capacity glass centrifuge tubes, and left for $10 \mathrm{~min}$. in boiling water bath. After alkali extraction, cooled in cold water, centrifuged for $10 \mathrm{~min}$. at $4500 \mathrm{rpm}$ and the supernatant subjected to protein determination. Protein content was determined by the method of (Lowry et al., 1951).

\section{Some Parameters Regulating Saccharomyces cerevisiae SCP Production}

The following parameters were examined for their effects on the production of $S$. cerevisiae SCP using the alkali-treated rice straw (RS1\% $\mathrm{NaOH}$ ). In each experiment the optimal conditions deduced from the previous experiments were considered. At the end of incubation period, the protein content was determined as mentioned before. 


\section{Incubation Temperature}

Incubation temperatures were examined on SCP production medium by $S$. cerevisiae at different temperatures viz: $20,25,30,35,40$, and $45^{\circ} \mathrm{C}$ for $24 \mathrm{hr}$.

\section{Incubation Period}

The influence of different incubation period on SCP production medium by $S$. cerevisiae at $30^{\circ} \mathrm{C}$ were applied at incubation for $0,12,24,36,48,72$ and $96 \mathrm{~h}$.

\section{Initial $\mathrm{pH}$ Value}

The effect of different initial $\mathrm{pH}$ values were studied on SCP production medium by $S$. cerevisiae growing on $(\mathrm{RS} 1 \% \mathrm{NaOH})$ at $30^{\circ} \mathrm{C}$ for 48 . Using citratephosphate buffer and phosphate buffer the $\mathrm{pH}$ were $3,3.5,4,4.5,5,5.5,6,6.5,7$, 7.5 and 8.

Inoculum Size: Different inoculum size of heavy cell suspensions $95 \mathrm{x}$ $10^{7} \mathrm{CFU} / \mathrm{ml}$ of the $S$. cerevisiae ranged between $0.0,0.1,0.3,0.5,1,2,4,6,8$ and $10 \mathrm{ml}$ were allowed to grow on $\mathrm{RS} 1 \% \mathrm{NaOH}$ at $30^{\circ} \mathrm{C}$ for $48 \mathrm{~h}$ and $\mathrm{pH} 4.5$.

Substrate Concentration: Different concentrations of $\mathrm{RS} 1 \% \mathrm{NaOH}(\mathrm{w} / \mathrm{v})$ was applied at concentrations $0.0,0.5,1,1.5,2,2.5,3,3.5,4,4.5$ and $5 \mathrm{~g} / 100 \mathrm{ml}$ on production medium.

Nitrogenous Source: Different nitrogen sources, peptone, yeast extract, beef extract, ammonium di-hydrogen phosphate, urea, potassium nitrate and ammonium sulphate were added to medium in equivalent to sodium nitrogen content that located into $0.3 \%(\mathrm{w} / \mathrm{v})$ of sodium nitrate except peptone, beef \& yeast extract were added at $0.1 \%(\mathrm{w} / \mathrm{v})$. Control was also prepared which contain $0.3 \%(\mathrm{w} / \mathrm{v}) \mathrm{NaNO}_{3}$.

Carbon Sources: Different carbon sources were added to the production medium. Control was performed without carbon source. The tested carbon sources were D-glucose, D-dextrose, D-fructose, sucrose, maltose and lactose. The carbon sources were added at an equimolecular level in $2 \%$ sucrose. Starch was added at $1 \%(\mathrm{~g} / \mathrm{v})$ medium.

Agitation: It was carried out by incubating the flasks containing the production media on the shaker at $150 \mathrm{rpm}$ at $30^{\circ} \mathrm{C}$ for $48 \mathrm{hr}$. Other flasks for each one were incubated under static condition at $30^{\circ} \mathrm{C}$ for $48 \mathrm{hr}$.

\section{Extraction and Nutritive Value of Saccharomyces cerevisiae SCP}

$S$. cerevisiae was grown under optimum conditions. The cells were harvested by centrifugation at $4000 \mathrm{rpm}$ at $4^{\circ} \mathrm{C}$ for $10 \mathrm{~min}$., washed twice with distilled water and dried at $70^{\circ} \mathrm{C}$ until constant weight. The dried yeast cells were preserved in dry place as a bulk of cells for use, as well as, for determination of nutritional content of yeast biomass (SCP). Its nutritive value was carried out by determination of moisture content, dry weight, ash, mineral content, protein content, carbohydrate content, lipid content, vitamins and amino acids content. 
Moisture Content and Biomass

Determination of moisture, constant weight and dry biomass was carried out according to Geary (1956).

\section{Ash and Mineral Content}

Total ash determination was done according to Reith et al. (1948). However, the mineral content was estimated according to A.S.T.M. (2002) using Inductively Coupled Argon Plasma, ICAP 6500 Due, Thermo Scientific, England. $1000 \mu \mathrm{g} / \mathrm{l}$ multi-element certified standard solution, Merck, Germany was used as stock solution for instrument standardization.

\section{Protein Content}

It was determined by micro-Kjeldahl method as described by Haphries (1956) for total nitrogen determined. The total nitrogen values are multiplied by the factors (6.25) to obtain the crude protein content.

Carbohydrate Content: Extraction and determination of total soluble carbohydrates were carried out according to Umbriet et al., (1969).

Lipids Content: Total lipids were determined according to the A.O.A.C. (1975) using Soxhlet lipid extractor apparatus.

Vitamins Content: Vitamin C content was determined according to the A.O.A.C. (1990). Vitamin B was determined using high performance liquid chromatography system (HPLC) according to Batifoulier et al. (2005).

Amino Acids Content: The amino acids content was determined by amino acid analyzer \{Eppendrof -LC3000\} according to Block et al. (1958).

\section{Results and Discussion}

In the present study, the production of SCP by S. cerevisiae was performed at different incubation temperature (ranged from $30-45^{\circ} \mathrm{C}$ ) for $24 \mathrm{hr}$. The data presented in Fig. 1 showed that, the maximum SCP productivities by $S$. cerevisiae $(0.3857 \mathrm{mg} / \mathrm{ml})$ was obtained at $30^{\circ} \mathrm{C}$ incubation temperature in presence of $\mathrm{RS} 1 \% \mathrm{NaOH}$. Above or below this temperature, the protein yield was decreased gradually. These results are in agreement with the results of several workers (Paraskevopoulos et al., 2003 and Zhang et al., 2008) who found that the maximum protein production by yeast and other organisms were obtained at $30^{\circ} \mathrm{C}$. On the other hand, the results are partially contradictory with that obtained by Anupama \& Ravindra (2001) and Gao et al. (2007) who reported that the optimum temperature for SCP production by Aspergillus niger was $28^{\circ} \mathrm{C}$. Zheng et al. (2005) found that the optimum temperature for SCP by Candida arborea was $29^{\circ} \mathrm{C}$. Xiao et al. (2009) also recorded optimum temperature ranged from $28^{\circ} \mathrm{C}$ to $32^{\circ} \mathrm{C}$ for mixed fermentation by A. niger and C. utilis. 


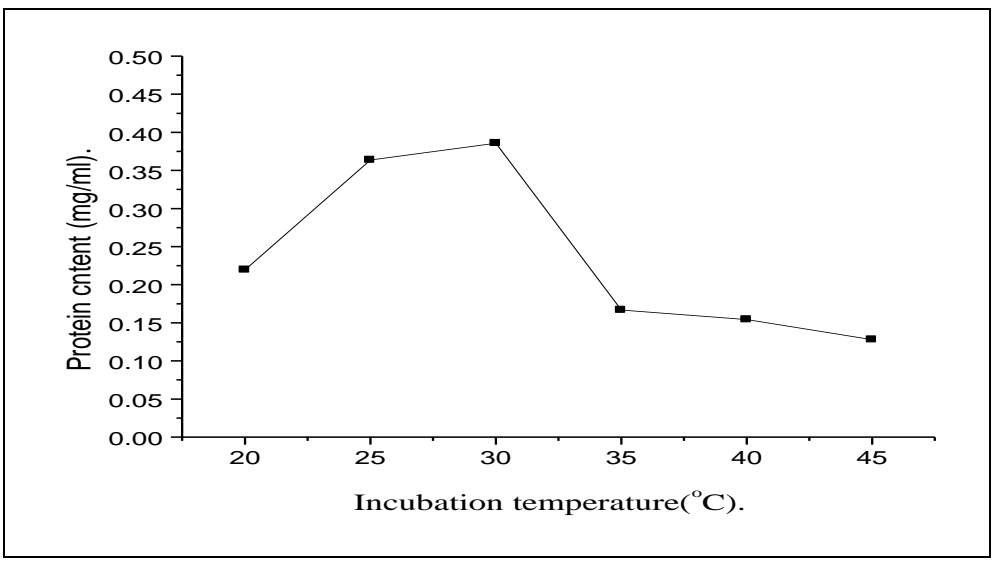

Fig. 1. Effect of different incubation temperatures on SCP productivity by S. cerevisiae.

\section{Incubation Period}

The results presented in Fig. 2 showed that, maximum yield of SCP was achieved after $48 \mathrm{hr}$. This result is more related with those obtained by Ghaly et al. (2005) who recorded protein production by yeast fermentation on acid cheese whey after 48hr. Also, Zhang et al. (2008) reported the same results, as maximum biomass protein production was after $48 \mathrm{hr}$ by Aspergillus oryzae. However, Rajoka et al. (2006) recorded optimum fermentation period of 3 days by Candida utilis for protein production.

In contrast to our results, Zhang et al. (2008) recorded that, Trichoderma viride grown on winery wastewater exhibited its ability to produce biomass protein within $24 \mathrm{hr}$. Gao et al. (2007) reported that, optimum incubation time was $56 \mathrm{hr}$ by Cryptococcus aureus G7a for SCP production. Silva et al. (2011) reported that, the optimal production for biomass production by yeast was obtained after $192 \mathrm{hr}$.

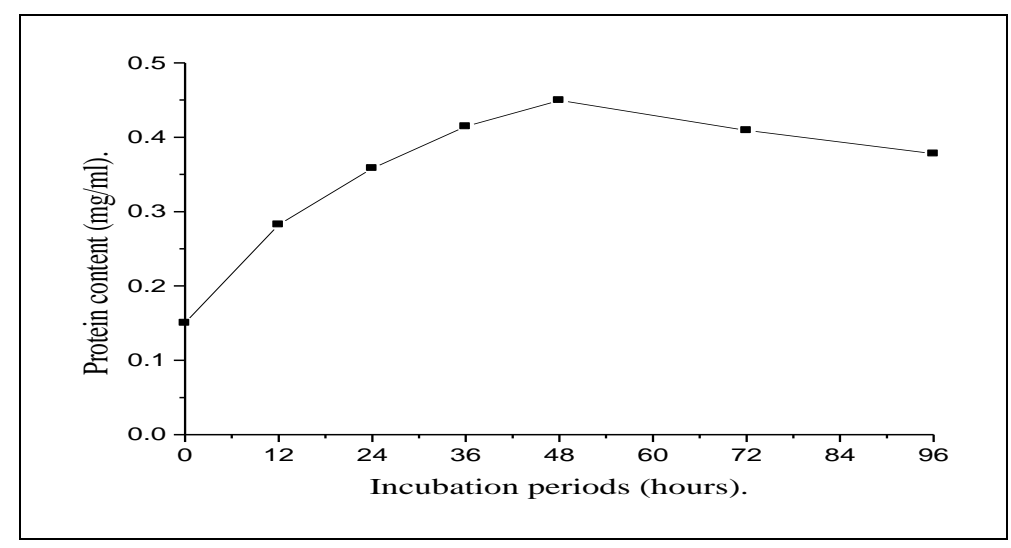

Fig. 2. Relation between different incubation periods and SCP produced by S. cerevisiae.

Egypt. J. Bot., 56, No. 1 (2016) 


\section{Initial $\mathrm{pH}$ values}

Different $\mathrm{pH}$ values (3-8) were also tested for its effect on SCP production. It could be concluded from the results illustrated in Fig. 3 that the $\mathrm{pH}$ value was 4.5 was the optimum for the highest yields by $S$. cerevisiae grown on $\mathrm{RS} 1 \% \mathrm{NaOH}$. This result is in agreement with Zhang et al. (2008) who reported that the maximum fungal biomass protein production was at $\mathrm{pH} 4.5$ and 5.5. On the other hand, Rajoka et al. (2006) showed that the optimum $\mathrm{pH}$ for SCP from yeast and other organism was 6.

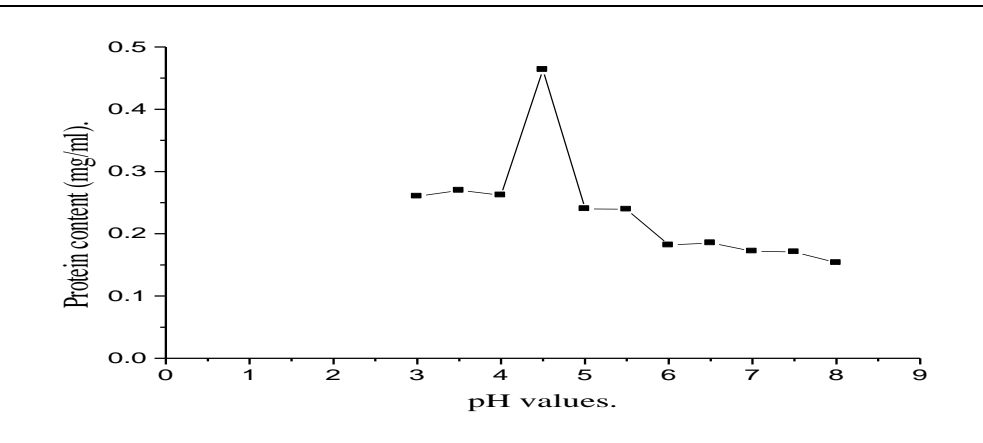

Fig. 3. Effect of different initial pH values on SCP yield by S. cerevisiae grown on $\mathrm{RS} 1 \% \mathrm{NaOH}$ at $30^{\circ} \mathrm{C}$.

Inoculum size

The results demonstrated that, the maximum yield of SCP was at an inoculum size of $S$. cerevisiae of $1 \mathrm{ml} / 100 \mathrm{ml}$ production media (Fig. 4). While, Zhang et al. (2008) found that, the maximum fungal biomass protein production was at $2.5 \%$ $\left(.5 \times 10^{8}\right)$. Zheng et al. (2005) reported the highest yield of biomass from Candida arborea at $5 \%$ inoculum size.

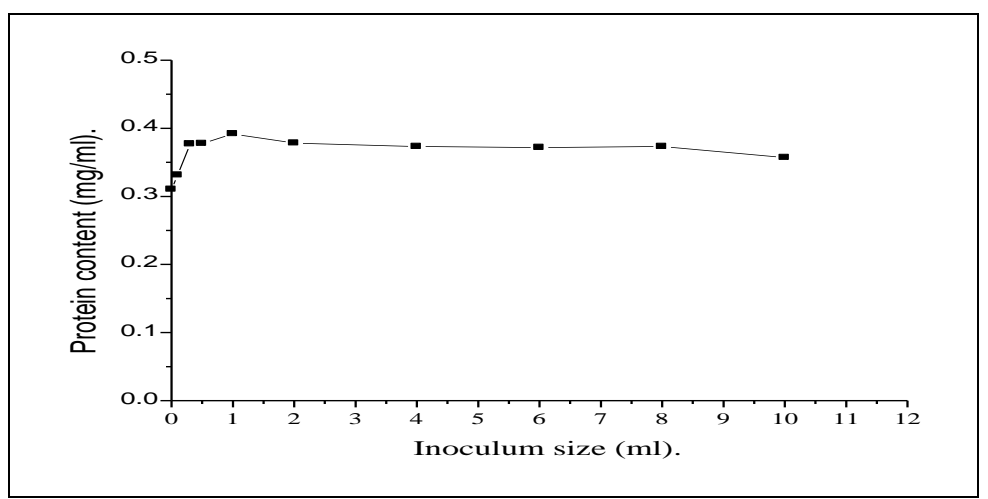

Fig. 4. Relation of inoculum size (ml) to SCP yield by $S$. cerevisiae grown on $\mathrm{RS} 1 \% \mathrm{NaOH}$ at $30^{\circ} \mathrm{C}$.

Egypt. J. Bot., 56, No. 1 (2016) 


\section{Substrate Concentration}

The production of SCP reached the maximum yield in presence of $2 \mathrm{~g}$ of $\mathrm{RS} 1 \% \mathrm{NaOH}$ as substrate in the production media (Fig. 5). Rajoka et al. (2006) used $9 \mathrm{~g} \%$ from rice polishing for SCP by Candida utilis and Gao et al. (2007) used $6 \mathrm{~g} \%$ Jerusalem artichoke for maximum production of SCP from Cryptococcus aureus G7a.

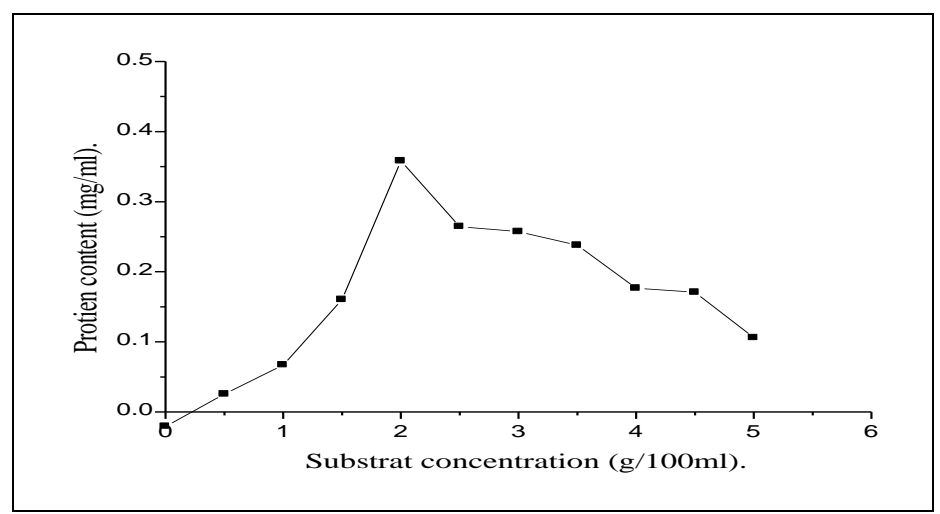

Fig. 5. Relation of substrate concentrations to SCP yields produced by $S$. cerevisiae grown on $\mathrm{RS1} \% \mathrm{NaOH}$ at $30^{\circ} \mathrm{C}$.

\section{Nitrogen Sources}

It is apparent from the results that the addition of nitrogen sources efficiently affects the SCP productivities by S. cerevisiae (Fig. 6). Addition of ammonium di-hydrogen phosphate to the production medium resulted in the highest amount of SCP. Zhang et al. (2008) reported that using $\left(\mathrm{NH}_{4}\right)_{2} \mathrm{SO}_{4}$ as nitrogen source give the highest yield of SCP by A. oryzae and A. niger.

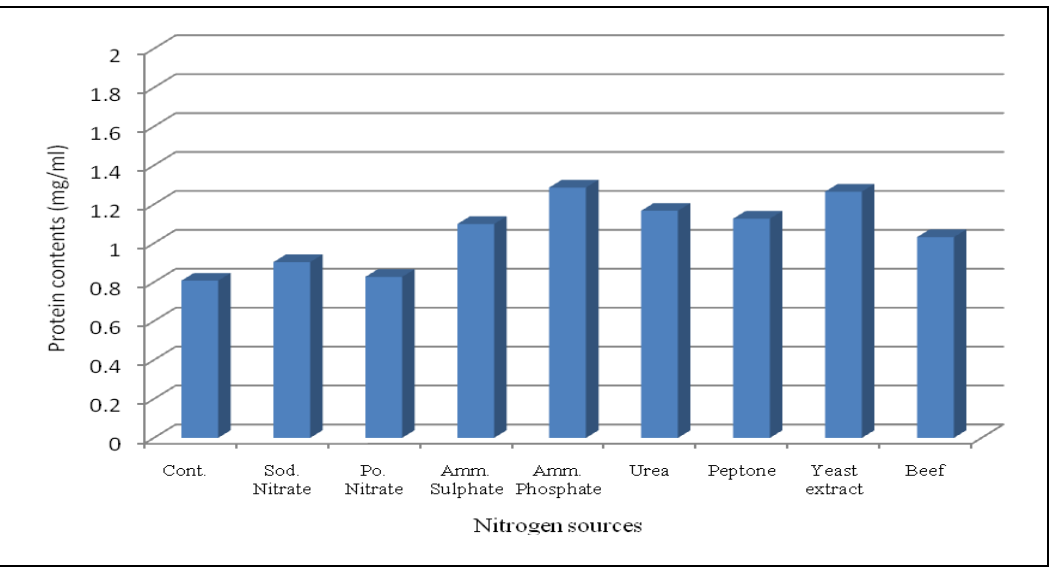

Fig. 6. Effect of different nitrogen sources on SCP productivity by $S$. cerevisiae grown on $\mathrm{RS} 1 \% \mathrm{NaOH}$ at $30^{\circ} \mathrm{C}$.

Egypt. J. Bot., 56, No. 1 (2016) 


\section{Carbon Sources}

Data emphasized that the maximum yield of SCP was achieved by the addition of lactose to the production medium (Fig. 7).Camacho-Ruiz et al. (2003) recorded that initial sugar concentration controlling SCP production by S. cerevisiae. Omar (2006) showed that ribose was the best carbon sources for give the highest yield of SCP by $S$. cerevisiae. Moreover, maximum yields of biomass, its protein content and total protein were produced by $S$. cerevisiae in the presence of $1 \%$ (w/w) glucose $(9.46 \mathrm{~g} / \mathrm{kg}$ orange peels; 40.89\%, w/w; 50.89\%, (w/w) Hossam (2013).

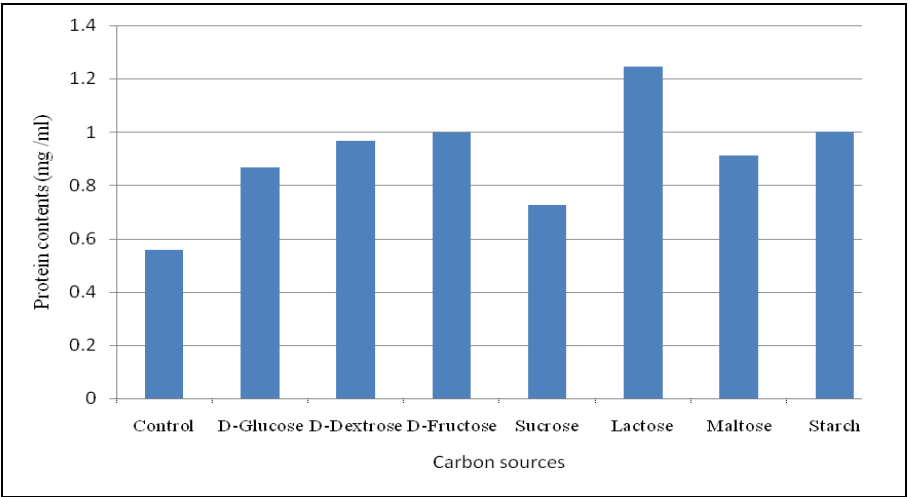

Fig. 7. Effect of carbon sources on SCP productivity by $S$. cerevisiae grown on $\mathrm{RS} 1 \% \mathrm{NaOH}$ at $30^{\circ} \mathrm{C}$.

\section{Agitation}

Results indicated that, the static condition is more favorable for protein production by yeast isolate (Fig. 8). On the contrary, Zhang et al. (2008) produced SCP in shaked conditions.

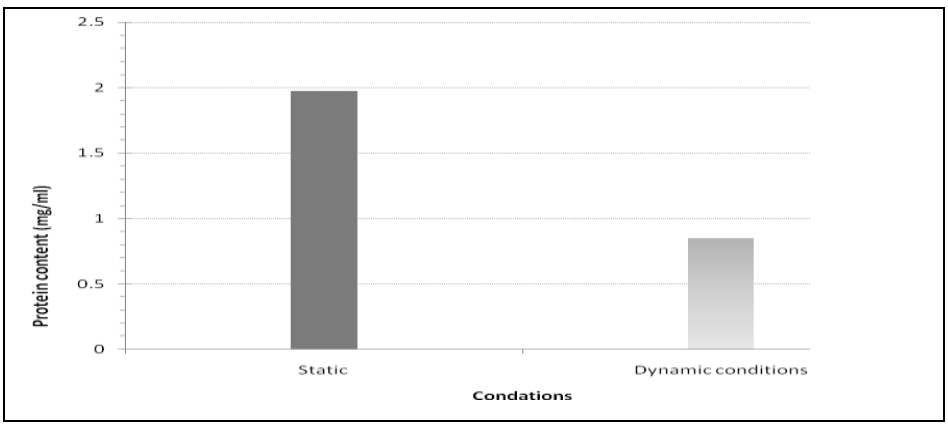

Fig. 8. Effect of agitation on SCP productivity by S. cerevisiae grown on $\mathrm{RS} 1 \% \mathrm{NaOH}$ at $30^{\circ} \mathrm{C}$. 
At the end of parameters optimization, S. cerevisiae was grown under optimum conditions and by the end of incubation period, cells were harvested and weighted as mentioned before. The biomass was found to be $35 \mathrm{~g} / \mathrm{l}$

\section{Analytical Characterization of Yeast Biomass Single Cell Protein}

The composition of single cell protein obtained from the fermentation of $\mathrm{RS} 1 \% \mathrm{NaOH}$ by $S$. cerevisiae is shown in Tables 2, 3, 4 \& 5. From Table 2 the moisture content of the dry cells was about $20.64 \%$ (w/w) which higher than that reported by Zepka et al. (2010) who found that the dry matter of SCP by Haloarcula sp was $79.36 \%$, (w/w).

This in partial agreement with Shojaosadati et al. (1999) who obtained dry matter $97.3 \%$ from yeast biomass. Concerning carbohydrates content, it was found to be $30 \%(\mathrm{w} / \mathrm{w})$, which is near the value (24\% carbohydrates content) obtained by Shojaosadati et al. (1999) SCP by Hansenula sp. In view of finding of other workers, Zepka et al. (2010) recoded that the carbohydrate content of SCP was $64.16 \%$. In this work, the lipids content showed high value $5.1 \%$ (w/w). The result was closely with the result (5.4\%) for lipid content recorded by Kurbanoulu (2001). On other hand Parajo et al. (1995) reported $9 \%$ of crude lipid in SCP of yeast. With respect to crude protein produced in our study, which found to be $28 \%$. Significant increases in protein content by yeast have been found by Ziino et al. (1999). Rajoka (2005) also recorded $60 \%$ crude protein by Candida utilis. Gao et al. (2007) showed that, the content of protein in marine yeast reached $53 \%$.

TABLE 2. Composition of yeast biomass SCP production

TABLE 2. Composition of yeast biomass SCP production
\begin{tabular}{|l|c|}
\hline Component & Yeast biomass SCP \\
\hline Moisture content $\%$ & 20.64 \\
\hline Dry weight $\%$ & 79.36 \\
\hline Ash content $\%$ & 84 \\
\hline Protein content $(\mathrm{mg} / \mathrm{ml})$ & 1.98 \\
\hline Crude protein $(\mathrm{g} / 100 \mathrm{~g})$ & 28 \\
\hline Carbohydrates content $(\mathrm{mg} / \mathrm{ml})$ & 0.26 \\
\hline Lipids content $(\mathrm{g} / 100 \mathrm{gm})$ & 5.05 \\
\hline
\end{tabular}

Table 3 illustrates single cell protein composition of elements. It was detected the SCP obtained is a good source for a number of elements but cadmium was not found. These results were higher than the values which previously reported for similar products by Paraskevopoulou et al. (2003).

The importance of vitamins content for the quality of SCP indicated from that, vitamin $\mathrm{C}$ is essential for normal growth and for many physiological functions of majority of marine fishes (Chi et al., 2006). Therefore, vitamin C and B contents in the $S$. cerevisiae were determined.

The data in Table 4 indicated the fact that yeast cells have the capacity to synthesize vitamin C and B by direct fermentation from simple sugars. Our results also showed that the yeast cells can synthesize higher amounts of vitamin

Egypt. J. Bot., 56, No. 1 (2016) 
C (32.64 mg/100g) of cell dry weight. These results were similar with Hancock et al. (2000) who reported that $S$. cerevisiae can synthesize a considerable amount of vitamin $\mathrm{C}$ under specific conditions. The results of this study also indicated that $S$. cerevisiae has high ability to synthesize vitamins B likes B1, B2, B3, B9 and $\mathrm{B} 12$ but not able to produce B6.

TABLE 3. Elemental analysis of some minerals of dry yeast cells S-RS1\% NaOH grown under static conditions.

\begin{tabular}{|c|c|}
\hline \multirow{2}{*}{ Parameter } & Results $\mathbf{~ m g} / \mathbf{k g}$ \\
\cline { 2 - 2 } & Elements \\
\hline Aluminum & 489.75 \\
\hline Boron & 4.775 \\
\hline Cadmium & 0.0 \\
\hline Cobalt & 0.93 \\
\hline Chromium & 46.15 \\
\hline Copper & 79.28 \\
\hline Iron & 1162.5 \\
\hline Manganese & 566.25 \\
\hline Molybdenum & 2.83 \\
\hline Nickel & 16.98 \\
\hline Lead & 12.93 \\
\hline Strontium & 68.15 \\
\hline Vanadium & 2.0 \\
\hline Zinc & 186.68 \\
\hline
\end{tabular}

TABLE 4. Vitamins content of dry yeast cells S-RS1\% NaOH grown under static conditions.

\begin{tabular}{|c|c|}
\hline Vitamins & mg /100g \\
\hline Thiamine B1 & 62.096 \\
\hline Riboflavin B2 & 1.654 \\
\hline Nicotinic acid B3 & 89.051 \\
\hline Pyridoxine B6 & - \\
\hline Folic acid B9 & 0.700 \\
\hline Cobalamine B12 & 1.750 \\
\hline Vitamin C & 32.64 \\
\hline
\end{tabular}

Data recorded in Table 5 showed that, the biomass cells had 16 kind of essential amino acids, These results show that the yeast strain $S$. cerevisiae was suitable for single-cell protein production. In agreement with our results Zheng et al. (2005) and Rajoka et al. (2006) recorded that, the biomass obtained from Candida utilis contained all the essential amino acids. 
TABLE 5. Amino acids content of dry yeast cells S-RS1\% NaOH grown under static conditions.

\begin{tabular}{|c|c|}
\hline Amino acids & $\mathrm{g} / \mathbf{1 0 0 g}$ \\
\hline Aspartic & 0.183 \\
\hline Threonine & 0.089 \\
\hline Serine & 0.085 \\
\hline Glutamic & 0.238 \\
\hline Proline & 0.083 \\
\hline Glycine & 0.112 \\
\hline Alanine & 0.121 \\
\hline Valine & 0.104 \\
\hline Methionine & 0.001 \\
\hline Isoleucine & 0.094 \\
\hline Leucine & 0.119 \\
\hline Tyrosine & 0.044 \\
\hline Phenylalanine & 0.077 \\
\hline Histodine & 0.280 \\
\hline Lysine & 0.093 \\
\hline Glutamine & 1.266 \\
\hline Arginine & 0.058 \\
\hline
\end{tabular}

\section{Conclusions}

The results of this work shown that the yeast isolate strain can be used to produce valuable SCP from low cost agro-industrial waste. This approach could be also used to minimize the environmental pollution. However, further investigations are necessary to scale up the treatment of agro-industrial wastes and product yield. The results also suggested that rice straw wastes which selected as raw materials was suitable and could be used to produce SCP by $S$. cerevisiae.

In order to serve as a health-conserving animal feed supplement, the microbial biomass must fulfill certain nutritional prerequisites including high contents of nutritional compounds such as protein content, mineral content, carbohydrate content, lipid content, vitamins and amino acids content. Analysis of the nutritional quality of biomass suggests that it could be used as a source of supplemental protein for animal feed.

\section{References}

A.O.A.C. (1975) "Official Methods of Analysis" (12 $2^{\text {th }}$ ed.) Washington, DC: Association of Official Analytical Chemists.

A.O.A.C. (1990) "Official Methods of Analysis" (15 th ed.) Association of Official Analytical Chemists, Inc. USA.

Egypt. J. Bot., 56, No. 1 (2016) 
A.S.T.M. (2002) American Society for Testing and Materials.

Anupama, X. and Ravindra, P. (2000) Value-added food: single cell protein. Biotechnol. $A d v .$, 18: 459-479.

Anupama, X. and Ravindra, P. (2001) Studies on production of single cell protein by Aspergillus niger in solid state fermentation of rice bran. Braz. Arc. Biol. Tec., 44: 79 88

Batifoulier, F., Verny, M-A. Besson, C. Demigne, C. and C. Remesy, (2005) Determination of thiamin and its phosphate esters in rat tissues analyzed as thiochromes on a RP-amide C16 column. Journal of chromatography B. 816: 67-72.

Becker, E.W. (2007) Micro-algae as a source of protein. Biotechnology Advances, 25 207-210.

Block, R.J., Durrum, E.l. and Zwery, B. (1958) "Manual of Paper Chromatography and Paper Electrophoresis”. $2^{\text {nd }}$ ed. Academic press in C. publishers, New York.

Camacho-Ruiz, Pérez-Guerra, N. and Pérez Roses, R. (2003) Factors affecting the growth of Saccharomyces cerevisiae in batch culture and in solid state fermentation. Electron. J . Environ. Agric. Food Chem., 2 (5): [531-542]

Chi, Z., Liu, Z., Gao, L., Gong, F., Ma, C., Wang, X. and Li, H. (2006) Marine yeasts and their applications in marine culture. J.Ocean. Univ. Chin., 5: 251-256.

Gao, L., Chi, Z. Sheng, J. Ni X. and Wang, L. (2007) Single - cell protein productions from Jerusalem artichoke extract by a recently isolated marine yeast Cryptococcus aureus G7a and its nutritive analysis. Appl. Microbiol. Biotechnol., 77: 825-832.

Geary P. J. (1956) Determination of moisture in solids. B.S.I.R.A. Research Report M24.

Ghaly, A.E., Kamal, M. and Correia, L.R. (2005) Kinetic modeling of continuous submerged fermentation of cheese whey for single cell protein production. Bioresource Technology, 96: $1143-1152$.

Hancock, RD., Galpin, J.R. and Viola, R. (2000) Biosynthesis of L ascorbic acid (vitamin C) by Saccharomyces cerevisiae. FEMS Microbial. Lett., 186: 245-250.

Haphries, E. (1956) Mineral component and ash analysis In: "Modern Methods of Plant Analysis”, Ed., K. Peach, and M.V. Tracey .156. Vol.1 Springer- Verlage, Berlin, p. 468 .

Hossam S. Hamdy (2013) Production of mini-food by Aspergillus niger, Rhizopus oryzae and Saccharomyces cerevisiae using orange peels. Romanian Biotechnological Letters, 18 (1): 7929-7946.

Kurbanoulu, E.B. (2001) Production of single cell protein from ram horn hydrolysate. Turk. J. Biol., 25: 371-377. 
Lowry, O. H., Rosebrough, N.J. Farr, A.L. and Randall, R.J. (1951) Protein measurement with the Folin phenol reagent. J. Bol. Chem., 193: 265-275.

Omar, Ali M. M. I. (2006) Microbiological utilization of Eichhorina crassipes under solid state fermentation. M. Sc. Thesis, bot. \& Microbiol., Dept., fac. Sci., Al-Azhar Univ., Cairo, Egypt.

Parajo, J.C., Santos, V. Dominguez, H. and Vaszquez, M. (1995) Protein concentrates from yeast cultured in wood hydrolysates. Food Chemistry, 53: 157-163.

Paraskevopouloua, A., Athanasiadisa, I. Kanellakib, M. Bekatoroua, A. Blekasa, G. and Kiosseogloua, V. (2003) Functional properties of single cell protein produced by Kefir Microflora. Food Research International, 36, 431-438.

Prado-Rubio, O. A., Jørgensen, J.B. and Jørgensen, S.B. (2010) Systematic model analysis for single cell protein production in a U-Loop Reactor. Computer Aided Chemical Engineering, 28: 319-324.

Rajoka, M.I. (2005) Production of single cell protein through fermentation of a perennial grass grown on saline lands with Cellulomonas biazotea. World Journal of Microbiology \& Biotechnology 21: 207-211.

Rajoka, M. I., Khan, S.H. Jabbar, M.A. Awan, M.S. and Hashmi, A.S. (2006) Kinetics of batch single cell protein production from rice polishing with Candida utilis in continuously aerated tank reactors. Bioresource Technology, 97: 1934-1941.

Rasoul-Amini, S., Ghasemi, Y. Morowvat, M.H. and Mohagheghzadeh, A. (2009) PCR amplification of $18 \mathrm{~S}$ rRNA, single cell protein production and fatty acid evaluation of some naturally isolated microalgae. Food Chemistry, 116: 129-136.

Ravindra, A. P. (2000) Value-added food: Single cell protein, Biotechnol. Adv., 18: 459-479.

Reith, J. F., Mossel, D.A.A. and de Kamer, J.H. (1948) Anal. Chem. Acta, 2: 359.

Shojaosadati, S.A., Khalilzadeh, R. Jalilzadeh, A. and Sanaei, H.R. (1999) Bioconversion of molasses stillage to protein as an economic treatment of this effluent. Resources, Conservation and Recycling, 27:125-138.

Silva, CF., Arcuri, S.L. Campos, C.R. Vilela, DM. Alves, J.G.L.F. and Schwan, RF. (2011) Using the residue of spirit production and bio ethanol for protein production by yeasts. Waste Management: 31:108-114.

Ugwuanyi J.O. (2008) Yield and protein quality of thermophilic Bacillus spp. biomass related to thermophilic aerobic digestion of agricultural wastes for animal feed supplementation. Bioresource Technology, 99: 3279-3290.

Umbriet, w.w., Burris, R.H. Stauffer, J.F. Cohen, P.P. Johnse, W.J. Leepage, G.A. Patler, U.R. and Scheider, W.C. (1959) "Manometric Techniques", a manual describing methods applicable to the study of tissue metabolism, pp. 239. Burgess publishing company.

Yang, Zhang, Yi. Gu, Jiang, Y. and Qin, B. (2009) Solid state fermentation of aquatic macrophytes for crude protein extraction. Ecological Engineering, 35: 1668-1676.

Egypt. J. Bot., 56, No. 1 (2016) 
Zepka, L. Q., Jacob-Lopes, E. Goldbeck, Leonor, R. Souza-Soares, A. and Queiroz, M.I. (2010) Nutritional evaluation of single-cell protein produced by Aphanothece microscopica Nageli. Bioresource Technology, 101:7107-7111.

Zhang, Z.Y., Jin, B. Z.H. Bai and Wang, X.Y. (2008) Production of fungal biomass protein using microfungi from winery wastewater treatment. Bioresource Technology, 99: $3871-3876$

Zheng, Y-G., Chen, X-L. and Zhao and Wang, Z. (2005) Microbial biomass production from rice straw hydrolysate in airlift bioreactors. Journal of Biotechnology, 118: 413420 .

Zhu, S., Wu Y., Yu, Z. Zhang, X. Wang, C. Yu, F. Jin, S. Zhao, Y. Tu, S. and Xue, Y. (2005) Simultaneous saccharification and fermentation of microwave/Alkali pretreated rice straw to ethanol. Biosystems Engineering, 92 (2): 229-235.

Ziino, M., R.B., Curto, R.B. Lo Salvo, F. Signorino, D. Chiofalo, B. and D. Giuffrida, D. (1999) Lipid composition of Geotrichum candidum single cell protein growth in continuous submerged culture. Bioresource Technology, 67: 7-11.

(Received 16/2/ 2015; accepted 12/4/2015) 


\section{استخدام قش الارز المعالج قلويا كبيئة رخيصة لإنتاج البروتين الحيوى بواسطة خميرة الخباز}

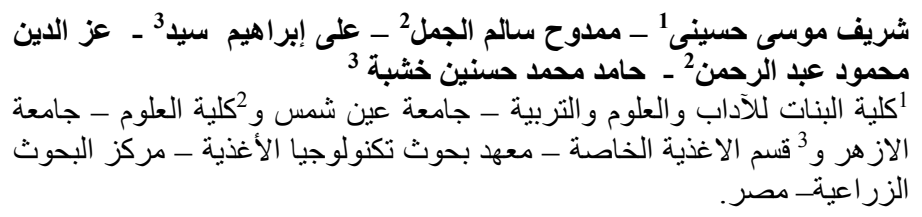

أجريت دراسة تتعلق بالتحويل البيولوجى لقش الارز المعالج قلوياً الى بروتين

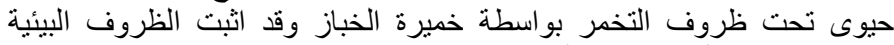

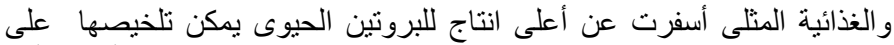

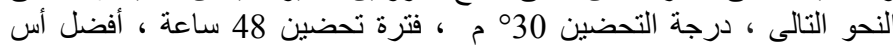

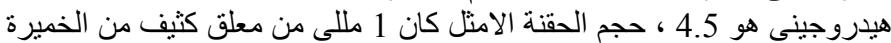

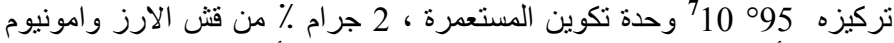

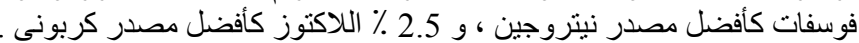

وقد تم الحصول على أعلى انتاجية من البروتين الحيوى تحت ظروف سئل ساكنة .

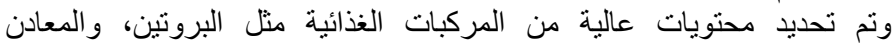

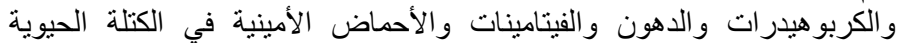

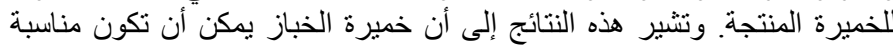
لإنتاج برونين حيوى من مخلفات رخيصة. 